\title{
Potential ecological risk of heavy metals in sediments from the Mediterranean coast, Egypt

\author{
Naglaa Farag Soliman ${ }^{*}$, Samir Mahmoud Nasr ${ }^{1}$ and Mohamed Abdelaziz Okbah²
}

\begin{abstract}
Background and aim: Mediterranean Sea, Egypt is an economically important marine environment. During the last decades there has been extensive increase in the levels of urbanization and industrialization along its coastal area. Therefore, the present work attempts to determine the status of heavy metals distribution in sediment samples, and their ecological risk assessment in the studied area.

Materials and methods: Twenty surfacial sediment samples were collected from different selected stations along the Egyptian Mediterranean Sea. The samples were homogenized and placed into sealed polyethylene bags, carried to the laboratory in an ice box and stored at $-20{ }^{\circ} \mathrm{C}$ in the dark until analysis.

Results: The results revealed that Fe had the highest mean value (243-38045 $\left.\mathrm{ggg}^{-1}\right)$ followed by Mn (17-1086 $\left.\mathrm{\mu gg}^{-1}\right)$, and a lower concentrations were found for $\mathrm{Co}\left(0.43-26.39 \mathrm{\mu gg}^{-1}\right)$ and $\mathrm{Cd}\left(0.04-0.47 \mathrm{\mu gg}^{-1}\right)$. Risk assessment showed that $\mathrm{Cd}$ had the highest ecological risk $(\mathrm{Er}=21.52)$, followed by $\mathrm{Pb}(\mathrm{Er}=3.01)$, while $\mathrm{Zn}$ had the lowest risk $(\mathrm{Er}=0.23)$. Both the ecotoxicological index method and the potential ecological risk index (RI) suggested that the combined ecological risk of the studied metals may be low. Multivariate statistical analysis (Cluster and Factor analysis) suggested that the lithogenic factor dominants the distribution of most part of the considered metals in the study area.

Conclusion: Multivariate analysis has been proved to be an effective tool for providing suggestive information regarding heavy metal sources and pathways. The results of this study provide valuable information about metal contamination in sediments along the Mediterranean Sea for over than $1200 \mathrm{~km}$.
\end{abstract}

Keywords: Heavy metals, Potential Ecological risk index, Sediments, Mediterranean coast, Egypt

\section{Introduction}

Heavy metals pollution of aquatic environment has become a great concern in recent years [1]. Heavy metals are among the most persistent of pollutants in the ecosystem such as water, sediments and biota because of their resistance to decomposition in natural condition. Toxicity appears after exceeding level of indispensability. Heavy metals become toxic when they are not metabolized by the body and accumulate in the soft tissues [2]. Under certain environmental conditions, heavy metals might accumulate up to toxic concentrations levels, and cause ecological damage [3]. Iron, zinc, copper and manganese are essential metals since they play important roles in biological systems [4], but they become toxic at higher concentrations. Non-essential metals such as $\mathrm{Pb}$,

\footnotetext{
* Correspondence: naglaa_farag2007@yahoo.com

${ }^{1}$ Department of Environmental Studies, Institute of Graduate studies and Research, Alexandria University, Alexandria, Egypt

Full list of author information is available at the end of the article
}

$\mathrm{Cd}$ are usually potent toxins even at relatively low concentrations and their bioaccumulation in tissues leads to intoxication, cellular and tissue damage, decreased fertility, dysfunction of a variety of organs and cell death [5]. Lead, cadmium, have been included in the regulations of the European Union for hazardous metals [6], while chromium and nickel are listed as hazardous metals by the United States Food and Drug Administration (USFDA) [7]. Metals have low solubility in water, get adsorbed and accumulated on bottom sediments [2]. While metals settled in sediments may be re-suspended and cause secondary contamination to the water environment, because sediments act both as a sink and a source for metals in the aquatic environment [8]. This fact converts the sediments in a permanent record of anthropogenic pollutants inputs [9]. Therefore, spatial surveys of metal concentrations in the sediments and then comparisons with non-polluted baselines are important to understand the mechanisms of 
accumulation and geochemical distribution of heavy metals in the aquatic systems and to provide basic information for the judgment of environmental health risks [10].

To date, many methodologies have been developed to assess ecological risks of heavy metals. However, most of them are suitable only for ecological assessment of a single contaminant (e.g., Geoaccumulation index method and Enrichment factor). In reality, many kinds of heavy metals usually accumulate simultaneously and cause combined pollution. To address this, Hakanson [11] developed the potential ecological risk index, which introduced a toxicresponse factor for a given substance and thus can be used to evaluate the combined pollution risk to an ecological system [12]. On the other hand, mean SQG quotient (mSQGQs) has been developed for assessing the potential effects of contaminant mixtures in sediments. Mean SQGQ have been calculated most frequently with SQGs derived with empirical approaches, such as the ERM, PEL values, in which measures of adverse effects were associate with, but not necessarily caused by specific chemicals [13].

The coastal zone of Egypt on the Mediterranean extends over $1200 \mathrm{~km}$ from Rafah to El-Salloum [14]. Unfortunately, most of the Egyptian coastal zones along the Mediterranean Sea are subjected to intense discharges of pollutants from numerous anthropogenic activities [15, 16]. Along the Mediterranean coast of Egypt, there are eight coastal governorates. These are from west to east Matruh, Alexandria, Behaira, Kafr ElSheikh, Damietta, Daqahliya, Port Said, and North Sinai. The enormous urban population and adjacent agricultural areas, all contribute to the pollution load reaching coastal waters. These derived either directly from coastal cities discharge points; the Rosetta branch of the River Nile, the Mahmudiya and Nubariya irrigation canals, drainage canals discharged directly to the sea, such as "El-Tabia and El- Ummum", or from coastal lagoons "lakes" Maryut, Idku, Burullus and Manzala. Large parts of the Nile Delta suffer from severe coastal erosion, although adequate protection and mitigation measures have been considered. Most of the coastal lagoons "lakes" are however in crisis, suffering from the excessive discharge of industrial, agricultural and domestic sewage flow [17]. Alexandria governorate coastal zone receives a large amount of metal pollution from the principle industries of this region include fertilizers, agrochemicals, pulp, paper, power plant, food processing, detergents, fibres, dyestuffs, textile, and building materials where, the daily average industrial discharge amounts to 30,000 and $128-261,000 \mathrm{~m}^{3}$ per day domestic sewage and 1-2 million cubic meters per day of agricultural wastes [18]. Rashid, El-Gamil, Damietta and Port Said are exposed to agricultural drains contaminated with hazardous industrial wastes, domestic sewage, organic matter, fertilizers and pesticides, in addition to oil pollution from ships and oil terminal as in Port Said and Damietta [19].

The aim of the present study was to: (1) provide the concentration and distribution of some heavy metals in the Egyptian Mediterranean Sea sediments. (2) evaluate the potential ecological risk levels of some heavy metals by applying the Potential Risk Index Method. (3) investigate the biological effects of some heavy metals concentrations using available Sediment Quality Guidelines (SQGs); and (4) identify the sources of the heavy metals with multivariate analyses.

\section{Materials and methods Study area}

The Egyptian Mediterranean coast extends between longitude $25^{\circ} 30^{\prime} \mathrm{E}$ and $34^{\circ} 15^{\prime} \mathrm{E}$ and extends northward to latitude $33^{\circ} \mathrm{N}$ [20] (Fig. 1). Economic activities in the coastal zone include agriculture, industry, fishes/aquaculture, and recreation beaches. Half of Egypt's industrial production comes from the delta, mainly from Alexandria. Main commercial ports are located at El Diekhila, Alexandria, Abu Quir, Idku, Damietta, Port Said, and east of Port Said [21].

\section{Sediment collection and pretreatment}

Twenty surfacial sediment samples $(0-5 \mathrm{~cm}$ depth) were collected during July 2010 from different selected stations along the Egyptian Mediterranean Sea using Peterson grab sampler (Fig. 1 and Table 1 ). The surface layer was chosen for this study, where this layer controls the exchange of metals between sediments and waters as well as constitutes a reserve of metals to which benthic organisms are exposed [20]. On the other hand, the sampling sites were selected to cover the expected polluted area due to industrial and other activities. Sufficient sediments had been collected from a particular site (six grabs). The samples were homogenized and placed into sealed polyethylene bags, carried to the laboratory in an ice box and stored at $-20^{\circ} \mathrm{C}$ in the dark until analysis.

\section{Analysis of sediment samples}

For metal analysis, sediment samples were oven dried at $60{ }^{\circ} \mathrm{C}$ for almost a week. After drying, sediments were grounded to a size $<63 \mu \mathrm{m}$ in an agate mortar then stored in plastic vials until analysis. Then, the samples were digested in an open system with a mixture of concentrated $\mathrm{HNO}_{3} / \mathrm{HClO}_{4} / \mathrm{HF}$ (3:2:1) according to Oregioni and Aston [22]. The determination of the metals in the sediment samples were performed with a SHIMADZU AA6650, Kyoto, Japan atomic absorption spectrophotometer equipped with a deuterium background corrector. An atomizer with an air/acetylene burner was used for determining all the investigated elements. All instrumental settings were those recommended in the manufacturer's manual book. Suitable internal chemical 


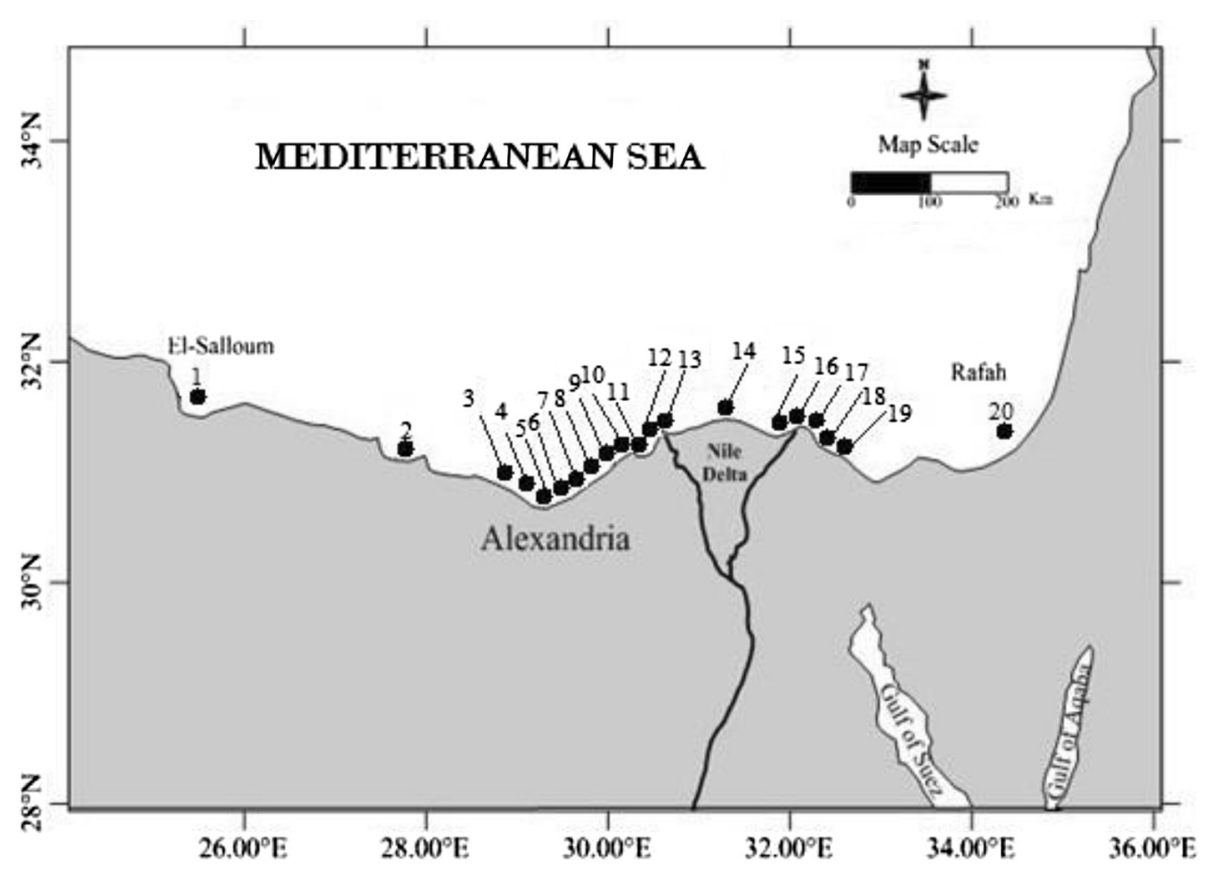

Fig. 1 Study area and location of sediment sampling station

Table 1 Physicochemical characteristics in sediments from the Egyptian Mediterranean coast

\begin{tabular}{|c|c|c|c|c|c|c|c|}
\hline \multirow[t]{2}{*}{ location } & \multirow[t]{2}{*}{ Station } & \multirow[t]{2}{*}{$\mathrm{CaCO}_{3} \%$} & \multirow[t]{2}{*}{ TOC\% } & \multirow[t]{2}{*}{$\mathrm{pH}$} & \multicolumn{3}{|c|}{ Grain size analysis } \\
\hline & & & & & Sand & Mud (Silt \& clay) & Texture \\
\hline El-Salloum & 1 & 34.79 & 0.26 & 8.26 & 86.85 & 13.15 & Very fine sand \\
\hline Baghoush & 2 & 94.45 & 0.32 & 8.21 & 99.99 & 0.01 & Fine sand \\
\hline El-Nobarreya & 3 & 95.49 & 0.72 & 8.26 & 100 & 0.0 & Fine sand \\
\hline El-Dikhaila & 4 & 85.42 & 0.34 & 8.31 & 99.96 & 0.04 & Fine sand \\
\hline El-Mex & 5 & 67.24 & 0.31 & 7.98 & 100 & 0.0 & Coarse sand \\
\hline Western Harbour & 6 & 95.57 & 0.38 & 7.82 & 100 & 0.0 & Very coarse sand \\
\hline $\mathrm{NIOF}$ & 7 & 91.64 & 1.00 & 7.84 & 98.26 & 1.74 & Fine sand \\
\hline Eastern Harbour & 8 & 93.56 & 0.57 & 8.38 & 99.99 & 0.01 & Fine sand \\
\hline Abu Qir & 9 & 22.11 & 0.22 & 8.19 & 99.98 & 0.02 & Fine sand \\
\hline Power station & 10 & 14.69 & 0.78 & 7.80 & 99.89 & 0.11 & Fine sand \\
\hline Maadia & 11 & 15.64 & 0.28 & 8.02 & 99.96 & 0.04 & Fine sand \\
\hline Rashid West & 12 & 3.83 & 0.05 & 7.93 & 100 & 0.0 & Fine sand \\
\hline Rashid East & 13 & 2.85 & 0.11 & 7.41 & 99.93 & 0.07 & Fine sand \\
\hline Burullus & 14 & 5.09 & 0.18 & 7.20 & 99.93 & 0.07 & Fine sand \\
\hline New Damietta & 15 & 6.08 & 0.29 & 7.97 & 99.67 & 0.33 & Very Fine sand \\
\hline Ras El-Barr & 16 & 4.87 & 0.14 & 7.63 & 99.57 & 0.43 & Very Fine sand \\
\hline El-Gamil West & 17 & 4.85 & 0.19 & 7.56 & 99.72 & 0.28 & Very Fine sand \\
\hline El-Gamil East & 18 & 5.64 & 0.20 & 7.77 & 99.76 & 0.24 & Very Fine sand \\
\hline Port Said & 19 & 7.32 & 0.14 & 7.48 & 99.60 & 0.40 & Very Fine sand \\
\hline Rafah & 20 & 6.33 & 0.20 & 7.79 & 100 & 0.0 & Fine sand \\
\hline
\end{tabular}


standards (Merck Chemicals, Germany) were used to calibrate the instrument.

Sediment $\mathrm{pH}$ was measured according to Yan et al. [23] with 1: 5 sediment to water ratio. Total organic carbon (TOC \%) was determined according to Walkely-Blak's wet oxidation method [24]. Total carbonate content of the sediment samples was determined by titration technique [25]. Grain size determination was made on the dried samples by the conventional sieving method [26].

\section{Quality control}

To remove any contamination, all glassware and plastic vials were washed with $10 \%$ nitric acid solution and rinsed thoroughly with Milli-Q water and dried. All reagents were Merck Chemiclas, Germany analytical grade or super pure quality. In order to check for the quality of the method applied for the analysis of heavy metals, the accuracy of the analytical method was estimated by analyzing sediment Standard Reference Material (IAEA-405): estuarine sediment, International Atomic Energy Agency, Vienna, Austria). Certified values of $\mathrm{Fe}, \mathrm{Mn}, \mathrm{Zn}, \mathrm{Cu}, \mathrm{Cr}$, $\mathrm{Ni}, \mathrm{Co}, \mathrm{Pb}$, and $\mathrm{Cd}$ are $37400,495,279,47.7,84,32.5$,

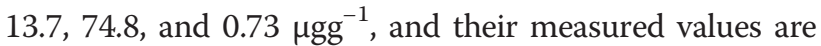
$38334,460,252,47,78,31,14,77$, and $0.70 \mu^{-1} g^{-1}$, respectively. The recovery of the selected elements ranged from 90 to $104 \%$ and the measurements of precision was under $10 \%$ RSD. The detection limits of the instrument for each metal were $0.023,0.033,0.036,0.047,0.039,0.040,0.037$,
0.044, and $0.025 \mathrm{mg} / \mathrm{l}$ for $\mathrm{Cd}, \mathrm{Cr}, \mathrm{Cu}, \mathrm{Co}, \mathrm{Fe}, \mathrm{Mn}, \mathrm{Ni}, \mathrm{Pb}$, and $\mathrm{Zn}$, respectively.

\section{Assessment of ecological risk Sediment quality guidelines}

Numerous sediment quality guidelines are used to protect aquatic biota from the harmful and toxic effects related with sediment bound contaminants [27]. These guidelines evaluate the degree to which the sediment-associated chemical status might adversely affect aquatic organisms and are designed for the interpretation of sediment quality. They are also used to rank and prioritize contaminated areas for further investigation [28]. The National Standard of China (NSC) GB18668-2002 [29] has defined three grades of marine sediment, in which the content of some heavy metals is regarded as parameters used to classify marine sediments quality (Table 2). According to this criterion, the first class quality is suitable for mariculture, nature reserves, and endangered species reserves, and leisure activities such as swimming; the second class quality can be used for industry and tourism sites; and the third class can only be used for harbors.

Another classification system is the Hong Kong environmental Protection Department (EPD) [30] Classification system. In this system 4 classes are used to classify the sediment quality. The first class showed to be classified as uncontaminated sediment (Class A). Whereas, the second class represented (Class B) slightly contaminated sediment.

Table 2 Total metals concentration $\left(\mu \mathrm{gg}^{-1} \mathrm{dry}\right.$ weight) in sediments from the Egyptian Mediterranean coast

\begin{tabular}{|c|c|c|c|c|c|c|c|c|c|}
\hline & $\mathrm{Cd}$ & $\mathrm{Co}$ & $\mathrm{Cr}$ & $\mathrm{Cu}$ & $\mathrm{Fe}$ & $\mathrm{Mn}$ & $\mathrm{Ni}$ & $\mathrm{Pb}$ & $\mathrm{Zn}$ \\
\hline Minimum & 0.04 & 0.43 & 4.08 & 0.46 & 243 & 17 & 1.65 & 3.34 & 2.05 \\
\hline Maximum & 0.47 & 26.39 & 297.95 & 26.26 & 38045 & 1086 & 60.25 & 53.67 & 62.21 \\
\hline Mean & 0.22 & 8.24 & 82.74 & 8.46 & 13256 & 381 & 25.93 & 13.17 & 22.19 \\
\hline Median & 0.17 & 4.47 & 53.1 & 7.32 & 7597 & 313.5 & 18.63 & 8.35 & 19.21 \\
\hline SD & 0.15 & 8.40 & 90.18 & 6.22 & 12911 & 305 & 20.96 & 11.90 & 15.84 \\
\hline CV \% & 69 & 102 & 109 & 74 & 97 & 80 & 81 & 90 & 71 \\
\hline TEL & 0.68 & - & 52.3 & 18.6 & - & - & 15.9 & 30.2 & 124 \\
\hline PEL & 4.2 & - & 160 & 108 & - & - & 42.8 & 112 & 271 \\
\hline$E R L$ & 1.2 & - & 81 & 34 & - & - & 21 & 47 & 150 \\
\hline ERM & 9.6 & - & 370 & 270 & - & - & 52 & 220 & 410 \\
\hline \multicolumn{10}{|l|}{ SEPA } \\
\hline Class I & 0.5 & - & - & 35 & - & - & - & 60 & 150 \\
\hline Class II & 1.5 & - & - & 100 & - & - & - & 130 & 350 \\
\hline Class III & 5 & - & - & 200 & - & - & - & 250 & 600 \\
\hline \multicolumn{10}{|l|}{ EPD } \\
\hline Class A & $<0.1$ & - & $<25$ & $<10$ & - & - & $<15$ & $<25$ & $<70$ \\
\hline Class B & $0.1-1.0$ & - & $25-50$ & $10-41$ & - & - & $15-35$ & $25-65$ & $70-150$ \\
\hline Class C & $1-1.5$ & - & $50-80$ & $55-64$ & - & - & $35-40$ & $65-75$ & $150-200$ \\
\hline Class D & $>1.5$ & - & $>80$ & $>64$ & - & - & $>1.5$ & $>75$ & $>200$ \\
\hline
\end{tabular}


The third and the fourth class were considered as moderately and seriously contaminated (Class C and Class D), respectively (Table 2).

U.S. National Oceanic Atmospheric Administration has developed Sediment Quality Guidelines (SQGs) for the assessment of sediment quality from the concentrations of contaminants using chemical and biological effects database [31]. The chemical concentrations corresponding to the 10th and 50th percentiles of adverse biological effects were called the effects-range-low (ERL) and ERM guidelines, respectively [31]. Another sediment quality guideline which is most widely used to assess the ecotoxicology of sediments is the TEL and PEL approach. This approach is based on the relation between measured concentrations of metals and observed biological effects, such as mortality, growth or reproduction of living organisms. Threshold effect level (TEL) refers to the concentration below which adverse effects are expected to occur only rarely and probable effect level (PEL) indicates the concentration above which adverse effects are expected to occur frequently occur [32].

\section{Mean PEL and ERM quotient}

Although background/reference concentrations do give a base to evaluate SQGs and are important in environmental studies, they provide little insight into the potential ecological impact of contaminants [33]. Based on the fact that heavy metals always occur in sediments as complex mixtures, the mean PEL and ERM quotient method has been applied to determine the possible biological effect of combined toxicant groups by calculating mean quotients for a large range of contaminants using the following equation:

$$
\text { ERM-Q or PEL-Q }=\sum\left[C_{i} /\left(E R M_{i} \text { or PEL } L_{i}\right)\right] / n
$$

Where $C_{i}$ is the concentration of element $i$ in sediments, $E R M_{i}, P E L_{i}$ the guidelines values for the element $i$ and $n$ is the number of metals. Mean quotients are considered as useful tools for reducing a large amount of contaminants into a single number. By calculating mean quotients it is assumed that adverse effects to marine organisms caused by individual chemicals are additional limitation is that this approach does not consider all the chemicals present in sediments but only those include in the SQG list [34]. Mean quotients can be used to identify, delineate and prioritize areas of potential concern with respect to quality of sediments [35]. ERMQ values of $<0.1,0.11-0.5,0.5-1.5$ and $>1.5$ related to $12 \%, 30 \%, 46 \%$ and $74 \%$ likehood, respectively, that sediments present toxicity in amphipod survival bioassays. Similarly, PELQ values of $<0.1,0.11-1.5$, $1.51-2.3$ and $>2.3$ coincide with $10 \%, 25.5,50 \%$ and $76 \%$ likehood of toxicity, respectively [31]. Consequently, four relative levels of priority (highly toxic, medium toxic, slightly toxic and non toxic) have been proposed.

\section{Potential ecological risk index method}

The assessment of the potential risk of the heavy metal contamination was proposed as a diagnostic tool for water pollution control purposes as a result of the increasing content of heavy metals in sediments and their subsequent release into the water, which could threaten ecological health [36]. Potential ecological risk index method advanced by Swedish scholar Hakanson, according to the characteristics of heavy metal and its environmental behavior, is an approach to evaluate the heavy metal contamination from the perspective of sedimentology. It not only considers heavy metal level in the soil, but also associates ecological and environmental effects with toxicology, and evaluates pollution using comparable and equivalent property index grading method [37]. According to this method, the potential ecological risk coefficient $\mathrm{E}_{\mathrm{r}}^{\mathrm{i}}$ of a single element and the potential ecological risk index RI of the multielement can be computed via the following equations:

$$
\begin{aligned}
& C_{f}^{i}=C_{s}^{i} / C_{n}^{i} \\
& E_{r}^{i}=T_{r}^{i} x C_{f}^{i} \\
& R I=\sum_{i=1}^{n} E_{r}^{i}
\end{aligned}
$$

where $C_{f}^{i}$ is the pollution coefficient of a single element of " $\mathrm{i}$ "; $\mathrm{C}_{\mathrm{s}}^{\mathrm{i}}$ is the measured level of sedimentary heavy metal; $C_{n}^{i}$ is the background level of sedimentary heavy metal; $\mathrm{T}_{\mathrm{r}}^{\mathrm{i}}$ is the toxic response factor for the given element of " $i$ ", which accounts for the toxic requirement and the sensitivity requirement. The toxic response factors for $\mathrm{Pb}, \mathrm{Cd}, \mathrm{Cr}, \mathrm{Cu}, \mathrm{Zn}$ and $\mathrm{Ni}$ and $\mathrm{Mn}$ were 5, 30, 2, 5, 1,5 and 1 , respectively $[11,38]$. Average shale values [39] and average crustal abundance [40] were commonly used to provide elemental background concentrations [41]. The average shale background concentration of global sediments [39] is selected as the reference baselines in this study.

According to Hakanson [11], the following terminologies are suggested for the $E_{r}$ and RI values: (1) $E_{r}<40$, low ecological risk; $40<\mathrm{E}_{\mathrm{r}} \leq 80$, moderate ecological risk; $80<\mathrm{E}_{\mathrm{r}} \leq 160$, appreciable ecological risk; $160<\mathrm{E}_{\mathrm{r}} \leq 320$, high ecological risk; and $>320$, serious ecological risk; (2) RI <150, low ecological risk; $150<\mathrm{RI}<300$, moderate ecological risk; $300<\mathrm{RI}<600$, high ecological risk; and $R I \geq 600$, significantly high ecological risk.

RI method covers a variety of researching domains, i.e., biological toxicology, environmental chemistry as 
well as ecology, and can evaluate ecological risks caused by heavy metals comprehensively [11].

\section{Statistical analysis}

Statistical methods were applied to process the analytical data in terms of its distribution and correlation among the studied parameters. MINITAB (version 14) package software was used for statistical analyses of the metal data. Basic statistical parameters such as range, mean, median, standard deviation (SD), and skewness were computed along with correlation analysis, while multivariate statistics in terms of principal component analysis (PCA) and cluster analysis (CA) were also carried out.

\section{Results and discussion} Heavy metals in sediment

Figure 2 shows the results of analyses of heavy metals in sediment samples in box and whisker plot. Statistical summary of the metal contents including the mean value, background value, standard deviation and variation coefficients are presented in Table 2. Among the 9 elements studied, concentrations of Fe and $\mathrm{Mn}$ were higher, whereas lower concentrations of Co and $\mathrm{Cd}$ were observed in the different sampling locations.

In general, the results obtained in this study were in the range observed in other Mediterranean countries (Table 3), or even lower in some cases. In this sense, cadmium and lead showed higher concentrations in
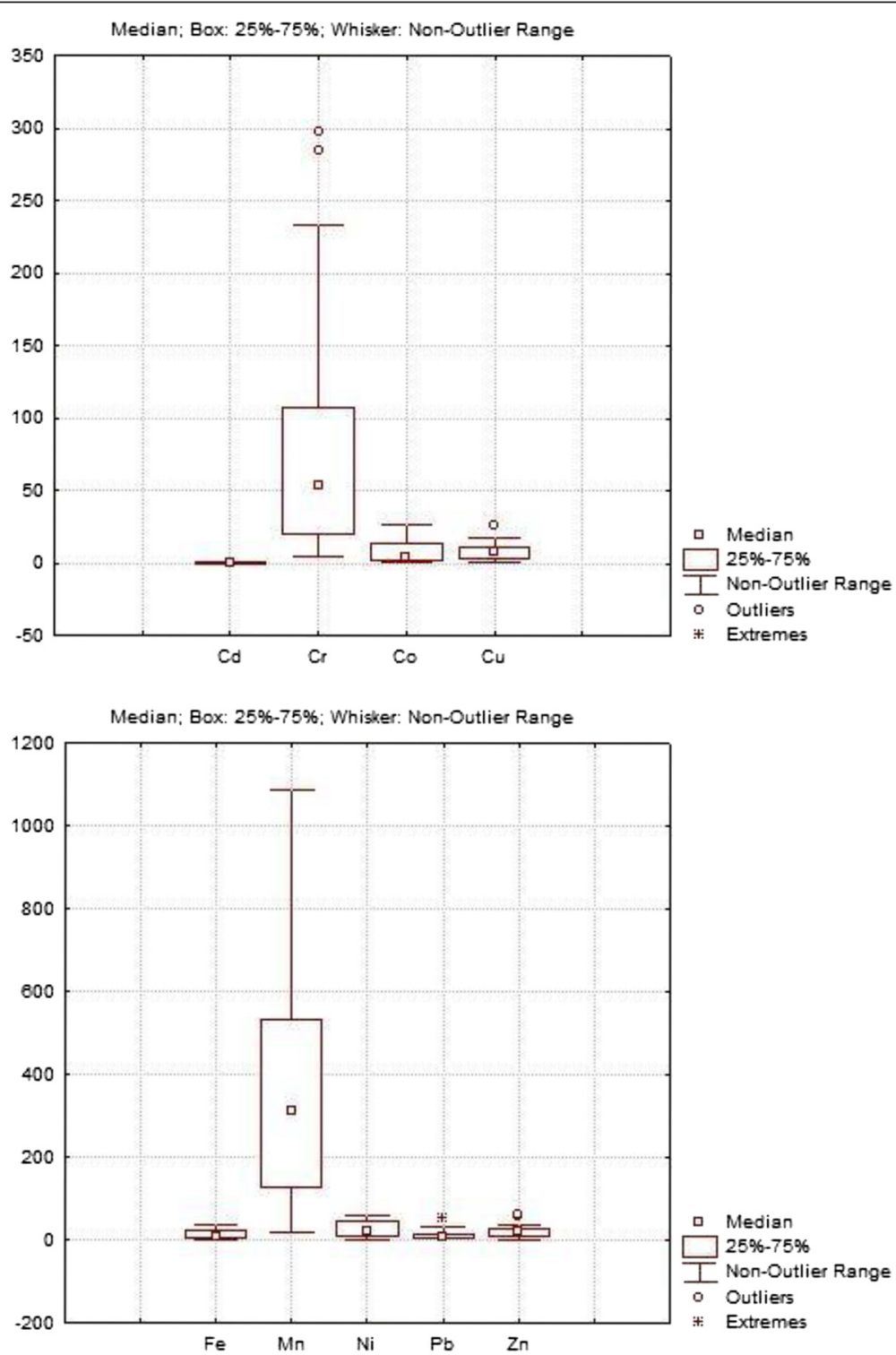

Fig. 2 Concentrations of heavy metals (in $\mathrm{\mu gg}^{-1}$ except Fe in $\mathrm{mgg}^{-1}$ ) plotted in box and Whisker method 
Table 3 Comparison between heavy metals concentrations obtained in this study with those obtained by other authors in Mediterranean Sea

\begin{tabular}{|c|c|c|c|c|c|c|c|c|c|}
\hline Location & $\mathrm{Cd}$ & $\mathrm{Cr}$ & $\mathrm{Cu}$ & Co & $\mathrm{Mn}$ & $\mathrm{Ni}$ & $\mathrm{Pb}$ & $\mathrm{Zn}$ & Reference \\
\hline Mediterranean Sea Egypt & $0.04-0.47$ & $4.08-297.95$ & $0.46-26.26$ & $0.43-26.39$ & $17-1086$ & $1.65-60.25$ & $3.34-53.67$ & $2.05-62.21$ & $\begin{array}{l}\text { Present } \\
\text { study }\end{array}$ \\
\hline $\begin{array}{l}\text { Malaga bay Mediterranean } \\
\text { Sea Spain }\end{array}$ & $0.021-0.283$ & $4.31-26$ & $6.57-21.2$ & - & - & $9.48-40.2$ & $7.92-37.1$ & - & {$[47]$} \\
\hline Mediterranean Sea Morocco & $0.14-0.27$ & $88.40-160.97$ & $4.09-29.12$ & $18.06-31.7$ & $256.56-651.66$ & $3.19-79.89$ & $33.11-47.97$ & $64.82-110.77$ & {$[48]$} \\
\hline Mediterranean Sea Turkey & - & - & - & - & 283-1192 & $28-240$ & $91.3-751$ & $86-970$ & [49] \\
\hline Ivra Complex Italy & - & $2568-2984$ & - & $100-117$ & $968-1053$ & $2040-2438$ & 0.25 & - & {$[50]$} \\
\hline Mediterranean Sea Libya & $5-10.5$ & $14.8-24.9$ & $9.1-22.7$ & $8.2-18.1$ & $14.3-49.4$ & $11.6-29.9$ & $8.9-56.9$ & $11.6-30.5$ & {$[51]$} \\
\hline $\begin{array}{l}\text { Eastern Mediterranean } \\
\text { Sea Egypt }\end{array}$ & $1.8-2.3$ & - & $4-9.4$ & - & $200.8-254.3$ & - & $18.4-24.8$ & $33.1-42.2$ & {$[52]$} \\
\hline Average shale & 0.3 & 90 & 45 & 19 & 850 & 68 & 20 & 95 & [39] \\
\hline
\end{tabular}

Libyan Mediterranean coast. Whereas, Co, Mn and $\mathrm{Ni}$ showed concentrations lower than those reported in Ivra complex, Italy. On the other hand, the values of $\mathrm{Cd}$, $\mathrm{Cr}, \mathrm{Cu}, \mathrm{Co}, \mathrm{Ni}$, and $\mathrm{Pb}$ obtained at the Moroccan Mediterranean coast were very close to those obtained in this study. However, the $\mathrm{Cr}$ concentrations were higher in the Egyptian Mediterranean coast than those measured in Malaga Bay, and the Libyan Mediterranean coast.

In order to establish relationships among metals and determine the common source of metals in the Egyptian Mediterranean coast, a correlation matrix was calculated for heavy metals in the sediments. The data showed that strong positive correlation exists between Fe and Mn $(r=0.92, p<0.01)$, Co $(r=0.96, p<0.01), \mathrm{Cr}$ $(r=0.69, p<0.01)$, and $\mathrm{Ni}(r=0.85, p<0.01)$. It means that these metals tend to accumulate together. The significantly positive correlation with Fe indicates that the metals were derived from similar sources and also moving together [42]. Significant correlation exists between $\mathrm{Zn}$ and $\mathrm{Cu}(r=0.80, p<0.01)$ and $\mathrm{Pb}(r=0.66, p<0.01)$, which suggested that these metals were redistributed in the sediments by the same physico-chemical processes or had a similar source [3]. The minor role of carbonate as metal carrier is reflected by the negative correlations between $\mathrm{Ni}(r=-0.81, p<0.01)$, Fe $(r=-0.68, p<0.01)$, Mn $(r=-0.68, p<0.01)$, Co $(r=-0.69, p<0.01)$ and $\mathrm{Cr}$ $(r=-0.65, p<0.01)$ with $\mathrm{CaCO}_{3}$. On the other hand, the negative correlation of TOC with $\mathrm{Ni}(r=-0.57, p<$ $0.01)$, Fe $(r=-0.48, p<0.05)$, Co $(r=-0.48, p<0.05)$ and $\mathrm{Cr}(r=0.53, p<0.05)$ suggested that TOC doesn't have important role in the binding of these elements [16].

\section{Assessment of ecological risk Sediment quality guidelines}

The sediments quality guidelines for the selected metals and a classification of the samples based on the guidelines are shown in Table 2. The contents of $\mathrm{Cd}, \mathrm{Cu}, \mathrm{Pb}$ and $\mathrm{Zn}$ at all samples are lower than the upper limit of the first class criteria of NSC GB 18668-2002. Comparing the sediment of the present study with classification system from Hong Kong environmental Protection Department (EPD) Classification system, the value of the mean Copper, Zinc, and Lead concentrations showed to be classified as uncontaminated sediment (Class A). Whereas, Nickel and Cadmium represented (Class B) contaminations. Sediments were considered as seriously contaminated (Class D) when comparing the mean concentration of Chromium with the classification system adopted by the Hong Kong Government [30].

Comparing results of the present study with ERL and ERM values, it was observed that $\mathrm{Cd}, \mathrm{Cu}$, and $\mathrm{Zn}$ at $100 \%$ of sampling stations are below the ERL value (1.2, 34 , and $150{\mu \mathrm{gg}^{-1}}^{-1}$, respectively which indicate that these metals are not likely to have adverse effects on animals that live in the sediment. Only one station (El-Mex) which had a $\mathrm{Pb}$ concentration $>\mathrm{ERL}$, indicated that $\mathrm{Pb}$ at El-Mex will likely to has effects on animals that live in this sediment. On the other hand, all the rest of the studied station had a concentration of $\mathrm{Pb}$ below the ERL value which indicates that $\mathrm{Pb}$ in the study area is not likely to have adverse effects on animals that live in sediments except station 5 in El-Mex. On the other hand, Ni at $30 \%$ of sampling stations (Rashid west, Burullus, New Damietta, El-Gamil east, Port Said and Rafah) had a value over the ERL value $(36.384,43.545,44.305,48.93$, 47.415 , and 27.79), respectively. This reflects that the adverse effects on animals live at these stations are frequently occurred. Stations 13, 16, and 17 in (Rashid east, Ras El-Barr and El-Gamil west), respectively had concentration of $\mathrm{Ni}$ above the ERM value (56.536, 56.413, and 60.246) which means that Ni probably has adverse effects on animals live in this sediment.

When compared to the TEL-PEL SQGs, the concentrations of $\mathrm{Cd}$ and $\mathrm{Zn}$ are lower than the TEL value at $100 \%$ of sampling stations, while $\mathrm{Pb}$ and $\mathrm{Cu}$ showed values lower than the TEL at $95 \%$ of sampling stations. 
On the other hand, in case of $\mathrm{Ni}, 20 \%$ of samples fall in the range between TEL and PEL at Abu Qir, Electric power station, Rashid west and Rafah indicating associated adverse biological effects may occasionally occur. However, exceedance of SQG values does not firmly guarantee the occurrence of deleterious ecological effects, unless they are also coherent with regional background levels [43]. Although about $35 \%$ of sediment samples had concentrations of $\mathrm{Ni}$ exceeding their respective PEL values at Rashid east, Ras El-Barr, New Damietta, Burrllus, El-Gamil east and west and Port Said, which were expected to have adverse biological effects occasionally, however, $100 \%$ of sediment samples had the concentration of $\mathrm{Ni}$ lower than their respective Background levels
$(68 \mathrm{mg} / \mathrm{kg}$ ) of average shale [39]. Furthermore, $\mathrm{Cr}$ exceeds the PEL value at $15 \%$ of samples (Rashid east, El-Gamil west and Port Said).

\section{Mean PEL and ERM quotient}

The $m$ - ERM-Q calculated for the sampling sites (based on metals $\mathrm{Cd}, \mathrm{Cr}, \mathrm{Cu}, \mathrm{Ni}, \mathrm{Pb}$ and $\mathrm{Zn}$ ) ranged from 0.01 to 0.34 (mean value of 0.15 ) (Fig. 3a), indicating that the combination of $\mathrm{Cd}, \mathrm{Cr}, \mathrm{Cu}, \mathrm{Ni}, \mathrm{Pb}$ and $\mathrm{Zn}$ may have a $30 \%$ probability of being toxic. Only eight stations (40\%) have ERMQ $(<0.1)$ and are categorized as non toxic and the rest of stations are categorized as slightly toxic. On the other hand, the $m-P E L-Q$ in surface sediments of the Egyptian Mediterranean coast range from

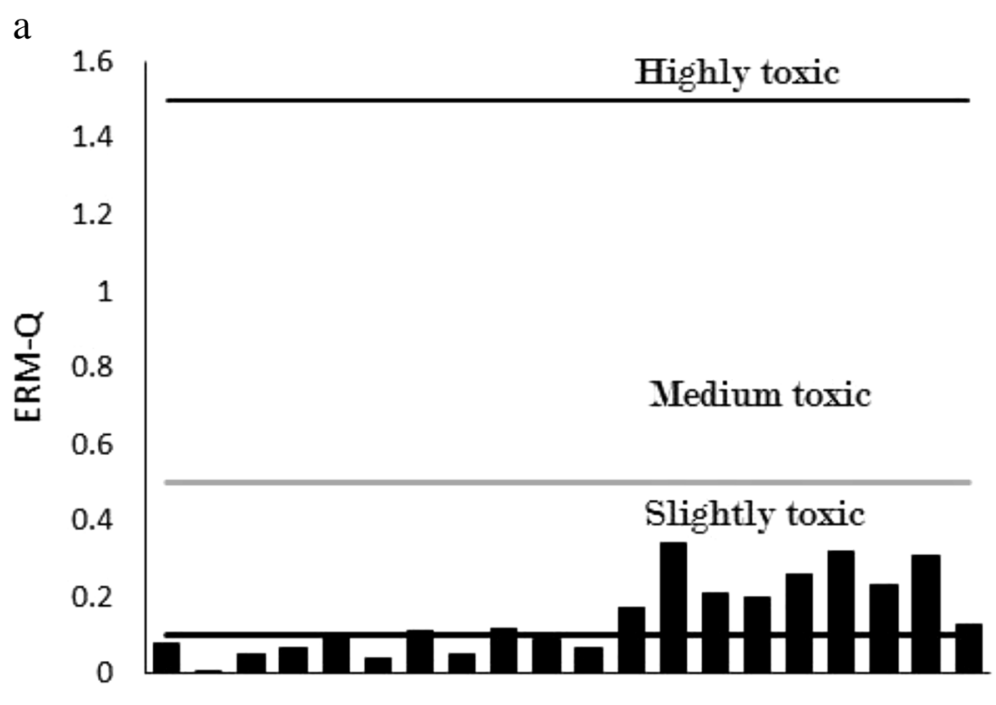

$\begin{array}{lllllllllllll}1 & 2 & 3 & 4 & 5 & 6 & 7 & 8 & 9 & 1011 & 121314 & 1516171819 & 20\end{array}$

$\mathrm{b}$

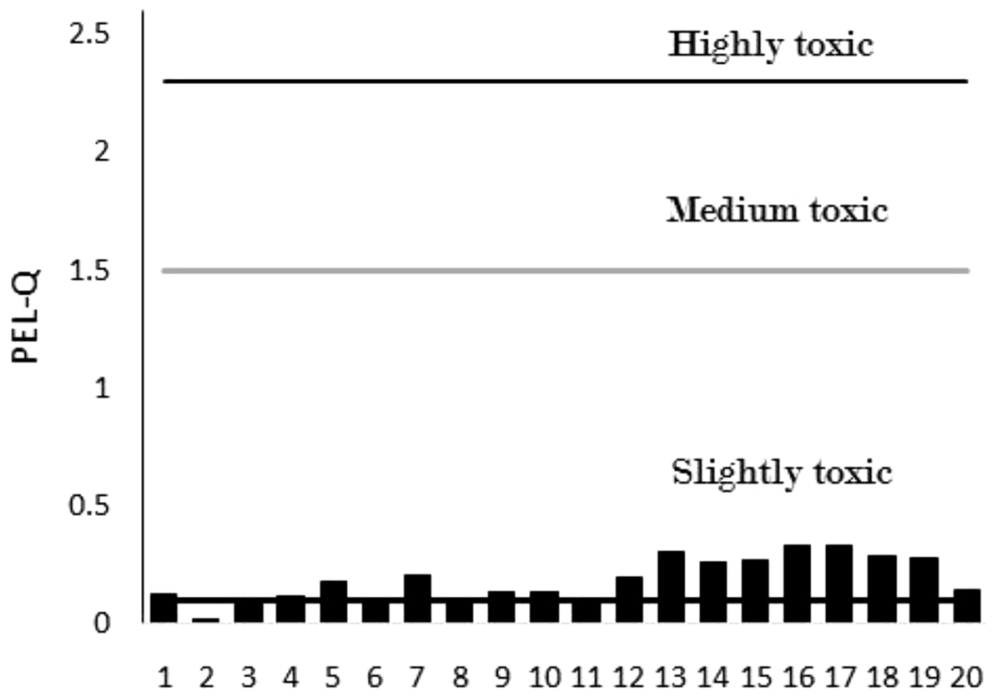

Fig. 3 a Estimated mean ERM-Q of surface sediments from the Egyptian Mediterranean coast. $\mathbf{b}$ Estimated mean PEL- Q of surface sediments from the Egyptian Mediterranean coast 
0.02 to 0.57 (mean value of 0.24 ) (Fig. 3b), indicating that the combination of $\mathrm{Cd}, \mathrm{Cr}, \mathrm{Cu}, \mathrm{Ni}, \mathrm{Pb}$ and $\mathrm{Zn}$ may have a $25 \%$ probability of being toxic. Furthermore, potential acute toxicity of contaminants in sediment samples could be estimated as the sum of the toxic units ( $\Sigma T U s)$ defined as the ratio of the determined concentration to PEL value [44]. In Fig. 4, the values of sum of TUs for each sampling stations based on the concentrations of $\mathrm{Cd}, \mathrm{Cr}, \mathrm{Co}, \mathrm{Cu}$, $\mathrm{Fe}, \mathrm{Mn}, \mathrm{Ni}, \mathrm{Pb}$ and $\mathrm{Zn}$ were shown. The sum of the toxic unit at Rashid east, El-Gamil west, and Port Said exhibit higher levels than other stations.

\section{Potential ecological risk index method}

To confirm the above evaluation, we further calculated the potential ecological risk index (RI) of surface sediments from the Egyptian Mediterranean coast. The results of evaluation on potential ecological risk factor $\left(\mathrm{E}_{\mathrm{r}}^{\mathrm{i}}\right)$ and the potential ecological risk index (RI) are summarized in Table 4. The order of potential ecological risk coefficient $\left(\mathrm{E}_{\mathrm{r}}^{\mathrm{i}}\right)$ of heavy metals in sediments of the Egyptian Mediterranean coast was $\mathrm{Cd}>\mathrm{Pb}>\mathrm{Ni}>\mathrm{Cr}>$ $\mathrm{Cu}>\mathrm{Mn}>\mathrm{Zn}$. The mean potential ecological risk coefficient of $\mathrm{Cd}, \mathrm{Cr}, \mathrm{Cu}, \mathrm{Mn}, \mathrm{Ni}, \mathrm{Pb}$ and $\mathrm{Zn}$ were all lower than 40 , which belong to low ecological risk. All the sampling sites were at low risk level where the RI values were much lower than 150 .

\section{Multivariate statistical analysis}

Multivariate analysis (i.e., Principal component analysis; PCA and Cluster analysis; CA) has been proved to be an effective tool for providing suggestive information regarding heavy metal sources and pathways [45].

The results of the principal component analysis; PCA on the data matrix obtained from total metal analysis of surface sediments along the study area are shown in Table 5. Two main components with Eigenvalues greater than 1 were determined, explaining $80.14 \%$ of the total variance. Apparently the result of PCA corresponds well with the correlation coefficients. The first component (PC1), with a variance of $55.059 \%$, was highly correlated with $\mathrm{Ni}, \mathrm{Fe}, \mathrm{Co}, \mathrm{Mn}$ and $\mathrm{Cr}$; correlation coefficients among this group of elements exceed 0.7 (0.945, 0.953,

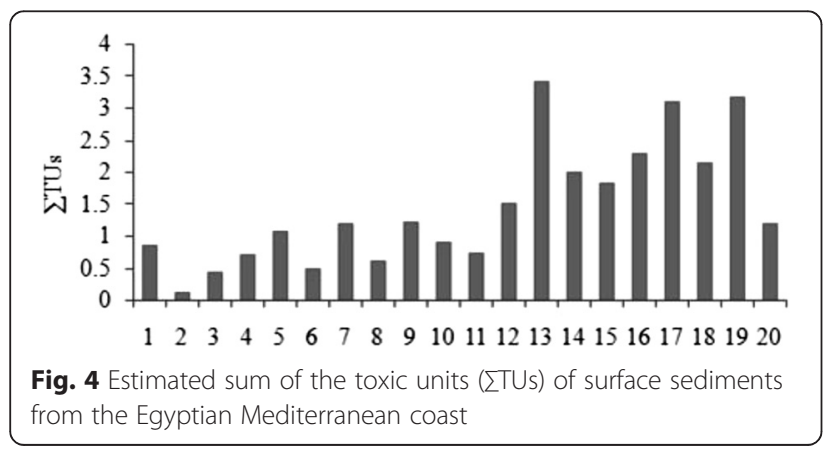

Table 4 Evaluation on potential risk of heavy metals pollution in sediments from the Egyptian Mediterranean coast

\begin{tabular}{|c|c|c|c|c|c|c|c|c|c|}
\hline \multirow[t]{2}{*}{ Station } & \multicolumn{7}{|c|}{ Potential ecological risk factor $\mathrm{E}_{\mathrm{r}}^{\mathrm{i}}$} & \multirow[t]{2}{*}{$\mathrm{RI}$} & \multirow{2}{*}{$\begin{array}{l}\text { Risk } \\
\text { grade }\end{array}$} \\
\hline & $\mathrm{Cd}$ & $\mathrm{Cr}$ & $\mathrm{Cu}$ & $\mathrm{Mn}$ & $\mathrm{Ni}$ & $\mathrm{Pb}$ & $\mathrm{Zn}$ & & \\
\hline 1 & 28.70 & 0.70 & 1.54 & 0.14 & 0.56 & 4.09 & 0.41 & 36.13 & Low \\
\hline 2 & 7.40 & 0.09 & 0.02 & 0.03 & 0.12 & 0.90 & 0.02 & 8.58 & Low \\
\hline 3 & 6.40 & 0.12 & 0.10 & 0.02 & 0.70 & 3.67 & 0.10 & 11.10 & Low \\
\hline 4 & 34.60 & 0.36 & 1.04 & 0.17 & 0.64 & 3.07 & 0.24 & 40.13 & Low \\
\hline 5 & 16.10 & 0.52 & 0.82 & 0.12 & 0.42 & 13.23 & 0.52 & 31.72 & Low \\
\hline 6 & 46.90 & 0.16 & 0.19 & 0.27 & 0.27 & 1.93 & 0.07 & 49.79 & Low \\
\hline 7 & 44.10 & 0.56 & 2.88 & 0.18 & 0.64 & 7.48 & 0.65 & 56.50 & Low \\
\hline 8 & 38.30 & 0.21 & 1.22 & 0.16 & 0.20 & 6.11 & 0.21 & 46.41 & Low \\
\hline 9 & 19.00 & 1.90 & 0.63 & 0.62 & 1.42 & 2.36 & 0.17 & 26.11 & Low \\
\hline 10 & 39.10 & 0.75 & 0.26 & 0.49 & 1.32 & 1.46 & 0.11 & 43.48 & Low \\
\hline 11 & 44.70 & 0.68 & 0.55 & 0.43 & 0.84 & 1.73 & 0.15 & 49.09 & Low \\
\hline 12 & 14.20 & 1.87 & 0.35 & 0.27 & 2.68 & 1.15 & 0.11 & 20.62 & Low \\
\hline 13 & 9.20 & 6.62 & 0.78 & 0.93 & 4.16 & 1.60 & 0.26 & 23.56 & Low \\
\hline 14 & 23.20 & 2.60 & 1.10 & 0.63 & 3.20 & 1.45 & 0.18 & 32.36 & Low \\
\hline 15 & 3.50 & 1.76 & 1.33 & 0.97 & 3.26 & 2.21 & 0.28 & 13.30 & Low \\
\hline 16 & 5.00 & 2.27 & 1.92 & 0.85 & 4.15 & 1.74 & 0.31 & 16.24 & Low \\
\hline 17 & 14.90 & 5.19 & 0.78 & 0.57 & 4.43 & 1.61 & 0.19 & 27.67 & Low \\
\hline 18 & 12.60 & 2.49 & 1.31 & 0.57 & 3.60 & 1.97 & 0.28 & 22.81 & Low \\
\hline 19 & 4.30 & 6.32 & 1.27 & 1.28 & 3.49 & 1.67 & 0.32 & 18.63 & Low \\
\hline 20 & 18.10 & 1.61 & 0.17 & 0.06 & 2.04 & 0.83 & 0.03 & 22.85 & Low \\
\hline Mean & 21.52 & 1.84 & 0.91 & 0.44 & 1.91 & 3.01 & 0.23 & 29.85 & Low \\
\hline
\end{tabular}

Table 5 Factor loadings on elements in sediments from the Egyptian Mediterranean coasta $(n=20)$

\begin{tabular}{cll}
\hline Element & $\mathrm{PC1}$ & $\mathrm{PC2}$ \\
\hline $\mathrm{Zn}$ & 0.037 & 0.966 \\
$\mathrm{Ni}$ & 0.945 & -.052 \\
$\mathrm{~Pb}$ & -0.542 & 0.669 \\
$\mathrm{Cd}$ & -0.648 & 0.209 \\
$\mathrm{Fe}$ & 0.953 & 0.190 \\
$\mathrm{Cu}$ & 0.229 & 0.876 \\
$\mathrm{Mn}$ & 0.911 & 0.110 \\
$\mathrm{Co}$ & 0.929 & 0.129 \\
$\mathrm{Cr}$ & 0.833 & -0.032 \\
Eigenvalue & 4.955 & 2.260 \\
\% variance explained & 55.059 & 25.115 \\
Cumulative \% variance & 55.059 & 80.174 \\
\hline
\end{tabular}

Extraction method: Principal component analysis Rotation method: Varimax with Kaiser Normalization 


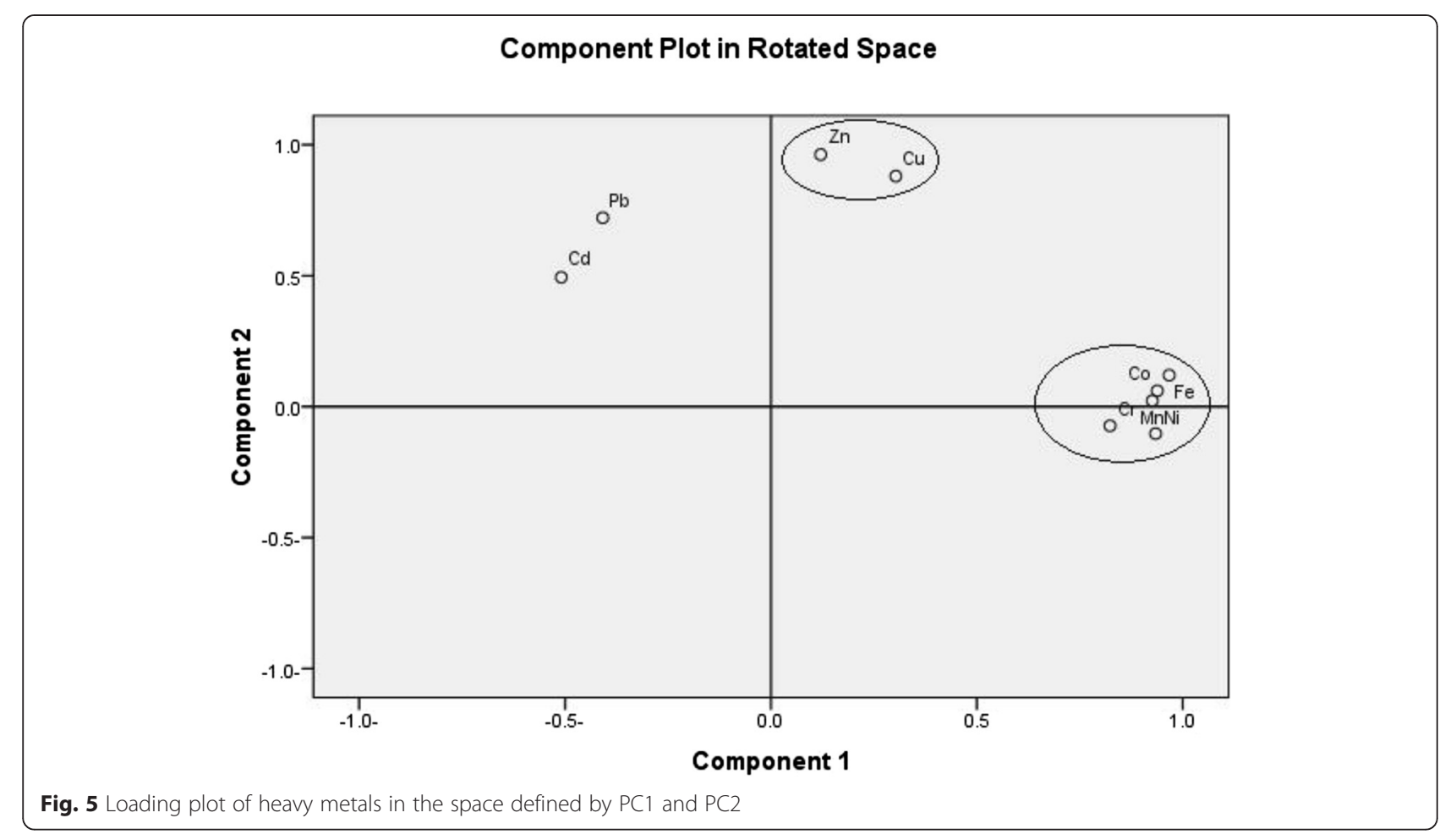

0.924, 0.911 and 0.833 , respectively). On the other hand, cadmium and lead showed strong negative loading $(-0.648$ and -0.542$)$. Co, $\mathrm{Ni}$ and $\mathrm{Cr}$ belong to the siderophile elements, and are main rocks forming elements. It is easy for them to enter into iron magnesium silicate minerals, because of their similar ionic radius. This element association is considered to represent the lithology of the study area, and a natural input, i.e., they are derived from terrigenous detritus material transported by surface runoff [46]. The second component (PC2) explained $25.11 \%$ of the total variance with significant loadings on $\mathrm{Zn}$ and $\mathrm{Cu}$ (0.966 and 0.876 respectively), which suggests similar sources. However, $\mathrm{Pb}$ also showed moderate positive loading (0.669), suggesting that the sources of $\mathrm{Pb}$ could be both natural and anthropogenic. Cadmium displays none of strong correlations between the other metals, suggesting that $\mathrm{Cd}$ has another different sources or pathways [45]. PC1 and PC2 together explained $80.14 \%$ of the total variance, indicating that the lithogenic factor dominates the

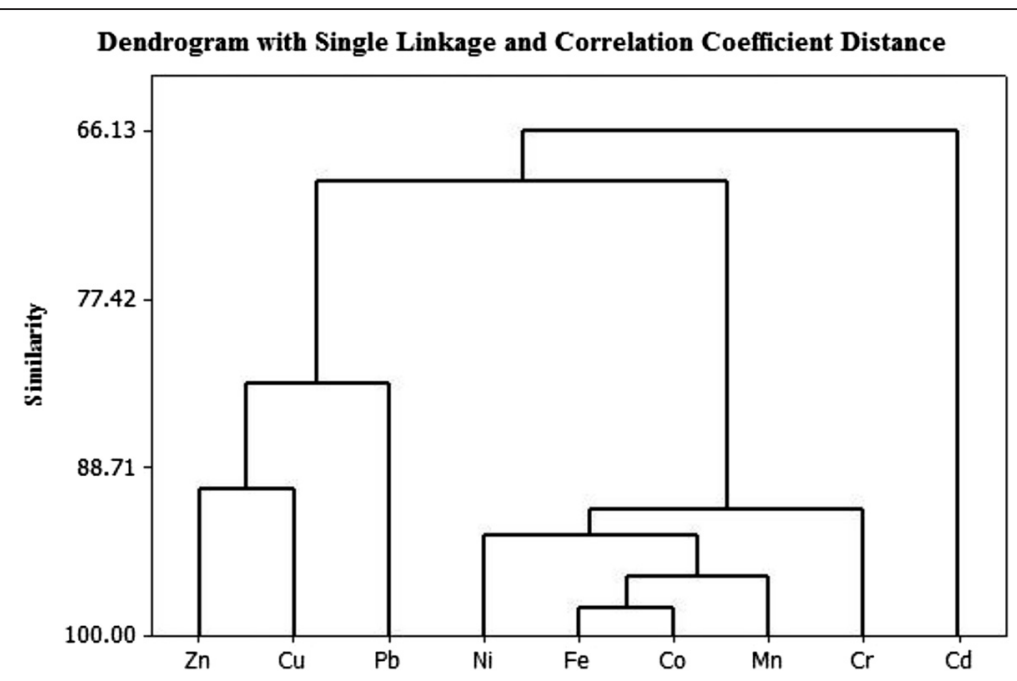

Fig. 6 Dendrogram showing cluster of variables on the basis of similarity 
distribution of most part of the considered metals in the study (Fig. 5).

Cluster analysis is often coupled with PCA to confirm results and provide grouping of variables [45]. In this study, CA was performed on the same data as PCA to understand the similarities among them. Figure 6 depicts a dendrogram with single linkage Euclidean and correlation coefficient distance. The cluster analysis results indicate two clusters: (1) $\mathrm{Pb}-\mathrm{Zn}-\mathrm{Cu}$; (2) Ni-Mn-Fe-Co-Cr in terms of similarities. This indicates that $\mathrm{Ni}, \mathrm{Mn}, \mathrm{Fe}, \mathrm{Co}$, and $\mathrm{Cr}$ appear to have originated mainly from natural sources. In addition, $\mathrm{Pb}, \mathrm{Zn}$ and $\mathrm{Cu}$ seem to drive partly from sources other than $\mathrm{Ni}, \mathrm{Mn}, \mathrm{Fe}, \mathrm{Co}$ and $\mathrm{Cr}$. This is consistent with our PCA results.

\section{Conclusion}

The results of this study provide valuable information about metal contamination in sediments along the Mediterranean Sea from El-Salloum to Rafah for over than $1200 \mathrm{~km}$. The distribution pattern of heavy metals in the sediments followed the sequence: $\mathrm{Fe}>$ $\mathrm{Mn}>\mathrm{Cr}>\mathrm{Ni}>\mathrm{Zn}>\mathrm{Pb}>\mathrm{Cu}>\mathrm{Co}>\mathrm{Cd}$. Association with adverse biological effects to aquatic biota was also assessed using the classification of sediments and sediment quality Guidelines (SQGs). $\mathrm{Ni}$ and $\mathrm{Cr}$ exceeded the probable effect level (PEL) in 35 and $15 \%$ of the sampling sites, respectively. The ecotoxicological index expressed as the mean ERM quotients (m-ERM-Q) suggested that the combination of $\mathrm{Cd}, \mathrm{Cr}, \mathrm{Cu}, \mathrm{Ni}, \mathrm{Pb}$ and $\mathrm{Zn}$ may have a $30 \%$ probability of being toxic while, the (m-PEL-Q) showed only a $25 \%$ probability of being toxic due to the combination of these metals. Similar results are also obtained by the potential ecological RI, with the average Er for heavy metals decreased in the order: $\mathrm{Cd}>\mathrm{Pb}>\mathrm{Ni}>\mathrm{Cr}>\mathrm{Cu}>\mathrm{Mn}>\mathrm{Zn}$. Multivariate statistical analysis evidenced significant correlations between $\mathrm{Fe}, \mathrm{Mn}, \mathrm{Co}, \mathrm{Cr}$ and $\mathrm{Ni}$, suggesting similar sources and/or similar geochemical processes controlling the occurrence of these metals in the sediments. This study supports metal pollution monitoring and control for the Egyptian Mediterranean Sea. It will be a useful tool to authorities in charge of sustainable marine management.

\section{Competing interests}

The authors declare that they have no competing interests.

\section{Authors' contributions}

SMN carried out the sediments collection. NFS carried out sediment pollution analysis and risk assessment. NFS, SMN and MAO participated in the sequence alignment and drafted the manuscript. They also, participated in the final version of manuscript and statistical analysis. All authors read and approved the final manuscript.

\section{Acknowledgment}

This research was part of a PhD dissertation of the first author. The authors would like to express their thanks to Water Pollution and Marine Environment Laboratory, Institute of Graduate Studies and Research, Alexandria University.

\section{Author details}

${ }^{1}$ Department of Environmental Studies, Institute of Graduate studies and Research, Alexandria University, Alexandria, Egypt. ²Department of Marine Chemistry, National Institute of Oceanography and Fisheries, Alexandria, Egypt.

Received: 17 February 2015 Accepted: 4 October 2015

Published online: 10 October 2015

\section{References}

1. Dabaradaran S, Naddafi K, Nazmara S, Ghaedi H. Heavy metals (Cd, Cu, Ni and $\mathrm{Pb}$ ) content in two fish species of Persian Gulf in Bushehr Port. Iran Afr J Biotechnol. 2010;37:6191-3.

2. Jain CK, Gupta H, Chakrapani GJ. Enrichment and fractionation of heavy metals in bed sediments of river Narmada. India Environ Monit Assess. 2008;141:35-47.

3. Bai JH, Cui BS, Chen B, Zhang KJ, Deng W, Gao HF, et al. Spatial distribution and ecological risk assessment of heavy metals in surface sediments from a typical plateau lake wetland. China Ecol Modell. 2011;222:301-6.

4. Hogstand C, Haux C. Binding and detoxification of heavy metals in lower vertebrates with reference to metallothionein. Comp Biochem Physiol C. 2011;100:137-214.

5. Damek-Proprawa M, Sawicka-Kapusta K. Damage to the liver, kidney and testes with reference to burden of heavy metals in yellow-necked mice from areas around steel workers and zinc smelters in Poland. Toxicology. 2003:186:1-10.

6. EC, 2001. Commission Regulation (EC) No. 466/2001 of 8 March 2001. Official Journal of European Communities 1.77/1

7. USFDA (United States Food and Drug Administration). Guidelines Document for cadmium in shellfish. Washington, DC: US. Department of Health and Human Services, Public Health Service Office, Office of Seafood(HFS-416); 1993. p. 44.

8. Malferrari D, Brigatti MF, Laurora A, Pini S. Heavy metals in sediments from canals for water supplying and drainage; mobilization and control strategies. J Hazard Mater. 2009;161:723-9.

9. Chen TR, Yu KF, Li Price GJ, Chi Q, Wei GJ. Heavy metal pollution recorded in Porites corals from Daya Bay, northern South China Sea. Mar Environ Res. 2010;70:318-26.

10. Simpson SL, Batley GE, Chariton AA, Stauber JL, King CK, Chapman JC, et al. Handbook for sediment quality assessment. Bangor: CSIRO; 2005.

11. Hakanson L. An ecological risk index for aquatic pollution control. A sedimentological approach. Water Res. 1980;14:975-1001.

12. Yang Z, Wang Y, Shen Z, Niu J, Tang Z. Distribution and speciation of heavy metals from the mainstream, tributaries, and lakes of the Yangtz River catchment of Wuhan. China J Hazard Mater. 2009;166:1186-94.

13. Long ER, MacDonald DD, Seven CG, Hong CB. Classifying the probabilities of acute toxicity in marine sediments with empirically derived sediment quality guidelines. Environ Toxicol Chem. 2000;19:2598-601.

14. Emam W, Saad AA, El-Moselhy KM, Owen NA. Evaluation of water quality of Abu Qir Bay, Mediterranean coast, Egypt. IJESE. 2013;4:47-54.

15. Dowidar NM. Productivity of the south-eastern Mediterranean. In: El-Sabh MI, Murty TS, editors. Natural and Man-Made Hazards. Dordrecht: Reidel Publishing Company; 1988. p. 477-98.

16. Okbah MA, Nasr SM, Soliman NF, Khairy MA. Distribution and contamination status of trace metals in the Mediterranean coastal sediments, Egypt. Soil Sediment Contam. 2014;23:656-76.

17. UNEP. Guidelines for Municipal Solid Waste Management: Planning in Small Islands Developing States in the Pacific Region, South Pacific Regional Environment Programme (SPREP). Western Samoa: Apia; 1999.

18. El-Nemr AM, Sikaily AE, Khaled A. Total and leachable heavy metals in muddy and sandy sediments of Egyptian coast along Mediterranean Sea. Environ Monit Assess. 2007;129:151-68.

19. Khaled A, El Nemr A, El Sikaily A, El-Sarraf WM. Assessment of heavy metals in the sediments of the Mediterranean coast of Egypt. EJAR. 2010;36:43-53.

20. Nasr SM, Khairy MA, Okbah MA, Soliman NF. AVS-SEM Relationships and Potential Bioavailability of Trace Metals in Sediments from the Southeastern Mediterranean Sea, Egypt. Chem Ecol. 2014;30:15-28.

21. Nasr SM, Soliman NF, Khairy MA, Okbah MA. Metals Bioavailability in Surface Sediments off Nile Delta, Egypt: Application of Acid Leachable Metals and Sequential Extraction Techniques. Environ Monit Assess. 2015;187:312. 
22. Oregioni B, Aston SR. Determination of selected trace metals in marine sediments by flame/flameless atomic absorption spectrophotometer. IAEA Monaco Laboratory Internal Report. Now cited in reference method in pollution studies No. 38, UNEP; 1984.

23. Yan C, Li O, Zhang X, Li G. Mobility and ecological risk assessment of heavy metals in surface sediments of Xiamen Bay and its adjacent areas. China Environ Earth Sci. 2010;60:1469-79.

24. Baruah TC, Barthakur HP. A textbook of soil analysis. New Delhi, India: Vikas Publishing House, Pvt. Ltd; 1997.

25. Black CA. Methods of soil analysis, part 2, Chemical and Microbiological properties. Madison, Wisc: American society of Agronomy Inc.; 1965.

26. Folk RL, Ward WC. Brazos river bar: a study in the significance of grain size parameters. J Sed Petrol. 1957;27:3-32.

27. McCready S, Birch GF, Long ER. Metallic and organic contaminants in sediments of Sydney Harbour, Australia and vicinity-a chemical dataset for evaluating sediment quality guidelines. Environ Int. 2006;32:455-65.

28. Dias De Alba M, Galindo-Riano MD, Casanuueva-Marenco MJ, Garcia-Vargas M, Kosore CM. Assessment of the metal pollution, potential toxicity and speciation of sediment from Algeciras Bay (South of Spain) using chemometric tools. J Hazard Mater. 2011;190:177-87.

29. SEPA (State Environmental Protection Administration of China). Marine Sediment Quality (GB 18668-2002). Beijing: Standards Press of China; 2002.

30. EPD. Marine water quality in Hong Kong. Hong Kong: Environment Protection department, Hong Kong Government Printer; 1992.

31. Long ER, McDonald D, Smith SL, Calder FD. Incidence of adverse biological effects within ranges of chemical concentrations in marine and estuarine sediments. Environ Manage. 1995;19:81-97.

32. Saleem M, lqbal J, Shah MH. Study of seasonal variations and risk assessment of selected metals in sediments from Mangla Lake, Pakistan. J Geochem Explor. 2012;125:144-52.

33. Gao X, Li P. Concentration and fractionation of trace metals in surface sediments of intertidal Bohai Bay, China. Mar Pollut Bull. 2012;64:1529-36.

34. Anders B, Reischmann T, Poller U, Kostopoulos D. Age and origin of granitic rocks of the eastern Vardar Zone, Greece: new constraints on the evolution of the Internal Hellenides. J Geol Soc. 2005;162:857-70.

35. Chapman PM, Mann GS. Sediment quality values (SQVs) and ecological risk assessment. Mar Pollut Bull. 1999;38:339-44.

36. Rahman MS, Saha N, Molla AH. Potential ecological risk assessment of heavy metal contamination in sediment and water body around Dhaka export processing zone, Bangladesh. Environ. Earth Sci. 2013; DOI 10.1007/s12665013-26315

37. Qui H. Studies on the potential ecological risk and homology correlation of heavy metal in the surface soil. JAS. 2010;2:194-201.

38. Xu ZQ, Ni SJ, Tuo XG. Calculation of heavy metals toxicity coefficient in the evaluation of potential ecological risk index. Environ Sci Tech. 2008;31:112-5.

39. Turekian KK, Wedepohl KH. Distribution of the elements in some major units of the earth's crust. Bull Geol Soc America. 1961;72:175-92.

40. Taylor SR. Abundance of chemical elements in the continental crust: a new table. Geochim Cosmochim Ac. 1972;28:1273-85.

41. Uluturhan E, Kontas A, Can E. Sediments concentrations of heavy metals in the Homa Lagoon (Eastern Agean Sea): Assessment of contamination and ecological risks. Mar Pollut Bull. 2011;62:1989-97.

42. Bhuiyan MA, Parver L, Isalm MA, Dampare SB, Suzuki S. Heavy metal pollution of coal mine affected agricultural soils in the northern part of Bangladesh. J Hazard Mater. 2009;173:384-92.

43. Farkas A, Erratico C, Vigano L. Assessment of the environmental significance of heavy metal pollution in surficial sediments of the River Po. Chemosphere. 2007;68:761-8.

44. Pedersen F, Bjørnestad E, Andersen HV, Kjølholt J, Poll C. Characterization of sediments from Copenhagen Harbour by use of biotests. Water Sci Technol. 1998;37:233-40.

45. Hu D, He J, Lu C, Ren L, Fan Q, Wang J, et al. Distribution characteristics and potential ecological risk assessment of heavy metals ( $\mathrm{Cu}, \mathrm{Pb}, \mathrm{Zn}, \mathrm{Cd})$ in water and sediments from Lake Dalinouer, China. Ecotoxol Environ Saf. 2013;93:135-44.

46. Krishna AK, Mohan KR, Murthy NN. Multivariate statistical approach for Monitoring of heavy metals in sediments: A case study from Wailpalli Watershed, Nalgonada district, Andhra Pradesh, India. Res J Environ Earth Sci. 2011;3:103-13.

47. Alonso Castillo ML, Sánchez Trujillo I, Vereda Alonso E, García de Torres A, Cano Pavón JM. Bioavailability of heavy metals in water and sediments from a typical Mediterranean Bay (Málaga Bay, Region of Andalucía, Southern Spain). Mar Pollut Bull. 2013;76:427-34.

48. Omar MB, Mendiguchı C, Er-Raioui H, Marhraoui M, Lafraoui G, Oulad-Abdellah MK, et al. Distribution of heavy metals in marine sediments of Tetouan coast (North of Morocco): natural and anthropogenic sources. Environ. Earth Sci. 2015; DOI 10.1007/s12665-015-4494-4

49. Neser G, Kontas A, Unsalan D, Uluturhan E, Altay O, Darılmaz E, et al. Heavy metals contamination levels at the Coast of Aliaga (Turkey) ship recycling zone. Mar Pollut Bull. 2012;64:882-7.

50. Hartmann G, Wedepohl KH. The composition of peridotite tectonites from the Ivrea Complex, northern Italy: residues from melt extraction. Geochim Cosmochim Ac. 1993;57:1761-82.

51. Nasr SM, Okbah MA, El Haddad HS, Soliman NF. Assessment of metals contamination in sediments from the Mediterranean Sea (Libya) using pollution indices and multivariate statistical analysis. GJAR. 2015;2:120-36.

52. Kaiser MF, Aboulela HA, El-Serehy HA, Ezz El-Din H. Heavy metals contamination of a Mediterranean coastal ecosystem, eastern Nile delta, Egypt. In: Dr. Stephen Young, editor. International perspectives on global environmental change. ISBN: 978-953-307-815-1, InTech; 2012

\section{Submit your next manuscript to BioMed Central and take full advantage of:}

- Convenient online submission

- Thorough peer review

- No space constraints or color figure charges

- Immediate publication on acceptance

- Inclusion in PubMed, CAS, Scopus and Google Scholar

- Research which is freely available for redistribution 